\title{
Establishment and partial characterization of a cell line from burbot Lota lota maculosa: susceptibility to IHNV, IPNV and VHSV
}

\author{
Mark P. Polinski ${ }^{1}$, John D. Drennan ${ }^{2}$, William N. Batts ${ }^{3}$, Susan C. Ireland ${ }^{4}$, \\ Kenneth D. Cain ${ }^{1, *}$ \\ ${ }^{1}$ Department of Fish and Wildlife Resources, College of Natural Resources, University of Idaho, Box 1102, Moscow, \\ Idaho 83843-1102, USA \\ ${ }^{2}$ Intervet/Schering-Plough Animal Health, Elkhorn, Nebraska 68022-2202, USA \\ ${ }^{3}$ US Geological Survey, Western Fisheries Research Center, 6505 NE 65th Street, Seattle, Washington 98115, USA \\ ${ }^{4}$ Kootenai Tribe of Idaho, PO Box 1269, Bonners Ferry, Idaho 83805, USA
}

\begin{abstract}
This study describes the development and partial characterization of a continuous fibroblastic-like cell line (BEF-1) developed from late stage embryos of North American burbot Lota lota maculosa. This cell line has been maintained for over $5 \mathrm{yr}$ and 100 passages in vitro. Cells were cultured using Eagle's minimum essential medium with Earle's salts (MEM) supplemented with GlutaMAX ${ }^{\mathrm{TM}}$, and $10 \%$ fetal bovine serum (FBS), $\mathrm{pH}$ 7.4. The addition of penicillin-streptomycinneomycin (PSN) antibiotic mixture $\left(0.05,0.05,0.1 \mathrm{mg} \mathrm{ml}^{-1}\right.$, respectively) did not negatively influence cell replication; however, the antimycotic Fungizone ${ }^{\mathrm{TM}}\left(2.5 \mu \mathrm{g} \mathrm{ml}^{-1}\right.$, amphotericin B) caused cell rounding and resulted in a severe decrease in cell proliferation. Optimal incubation temperature has been observed between 15 and $23^{\circ} \mathrm{C}$, and at these temperatures cultures are routinely passed using standard trypsinization methods every 5 to $7 \mathrm{~d}$ at a split ratio of 1:3 or 1:4. The cell line was susceptible to isolates of the $\mathrm{M}$ and $\mathrm{U}$ North American genotypes of infectious hematopoietic necrosis virus (IHNV), and to isolates of genotypes I, IVa, and IVb of viral hemorrhagic septicemia virus (VHSV). In contrast, the cell line was refractory to infection by 2 North American isolates of infectious pancreatic necrosis virus (IPNV) from serotypes A1 and A9. This cell line provides a new laboratory tool, will allow further investigation into viral diseases of burbot and possibly other species, and is the first immortalized cell line reported from a species in the Gadidae (cod) family.
\end{abstract}

KEY WORDS: Cell line $\cdot$ Burbot $\cdot$ Viral susceptibility $\cdot$ IHNV $\cdot$ IPNV $\cdot$ VHSV

Resale or republication not permitted without written consent of the publisher

\section{INTRODUCTION}

Cell lines of fish have found merit for a wide range of laboratory investigations including toxicology, pathogen isolation and amplification, genetic regulation and expression, and DNA replication and repair (Babich \& Borenfreund 1991, Bols \& Lee 1991). Additionally, the relative ease of culture and propagation of fish cell lines makes them ideal as instructional models or for studies of cell-virus interactions (Nicholson 1989, Fryer \& Lannan 1994). Fryer and Lannan (1994) summarized information on 125 fish cell lines derived from 52 spe- cies, and in the decade and a half since their review a substantial number of additional cell lines have been established. Nevertheless, a cell line from the Gadidae (cod) family has yet to be described.

Burbot are the only gadid to have a complete freshwater lifecycle and are widely distributed across the northern reaches of the Holarctic ecozone (McPhail \& Paragamian 2000). The unique life history of burbot has made it particularly susceptible to anthropogenic habitat encroachments (Paragamian \& Willis 2000), and dwindling populations have been observed worldwide (Pulliainen et al. 1992, Fisher 2000, Paragamian 
2000, Paragamian et al. 2000). In recent years, conservation aquaculture programs have become established both in Europe (Harzevilli et al. 2003, Vught et al. 2008) and North America (Jensen et al. 2008, Jensen et al. 2008b, Jensen et al. 2008c) to aid in the recovery of this species. Such efforts have raised concerns regarding disease susceptibility in burbot; an issue that has remained largely unexplored.

The development of a burbot cell line provides a tool for the detection of, and research into, intracellular pathogens of this species. The need for species-specific cell lines has been identified for fish pathogens such as white sturgeon iridovirus (WSIV) (Hedrick et al. 1991), which can only be cultured in sturgeon cell lines (OIE 2003). Although a similar virus has not been identified in burbot, the development of a cell line derived from burbot tissue should provide a useful tool for the study of burbot-specific viruses.

Three known viral pathogens of fish, viral hemorrhagic septicemia virus (VHSV), infectious hematopoietic necrosis virus (IHNV), and infectious pancreatic necrosis virus (IPNV), are of particular concern for burbot conservation aquaculture due to the close proximity and distribution of burbot to known viral reservoirs and the relatively unknown disease susceptibility or potential carrier status of this species. Therefore, the primary goal of this study was to develop a tool for laboratory diagnostics and studies into pathogen-cell interactions for burbot.

\section{MATERIALS AND METHODS}

Primary cell culture and subculture. Two late stage embryos from North American burbot Lota lota maculosa less than $1 \mathrm{~h}$ post hatch were obtained from the Aquaculture Research Institute at the University of Idaho, Moscow, USA. Samples were minced with a scalpel in a Petri dish containing minimal essential medium (MEM) with Earle's salts supplemented with GlutaMAX ${ }^{\mathrm{TM}}\left(\mathrm{Gibco}^{\circledR}\right), \quad 10 \%$ fetal bovine serum (FBS), penicillin-streptomycin-neomycin (PSN) antibiotic mixture $\left(0.05,0.05,0.1 \mathrm{mg} \mathrm{ml}^{-1}\right.$, respectively; Gibco $\left.{ }^{\circledR}\right)$, pH to $7.4\left(\mathrm{MEM}_{\mathrm{A}}-10\right)$. Resultant cells were centrifuged at $200 \times g$ for $5 \mathrm{~min}$ at $4^{\circ} \mathrm{C}$ and the pellet resuspended in $10 \mathrm{ml}$ fresh $\mathrm{MEM}_{\mathrm{A}}$ supplemented with $20 \%$ FBS $\left(\mathrm{MEM}_{\mathrm{A}}-20\right)$. Cells were seeded into a $25 \mathrm{~cm}^{2}$ flask and incubated at $15^{\circ} \mathrm{C}$. Medium was replaced after $24 \mathrm{~h}$. This primary culture (burbot embryo fibroblast; BEF-1) and subsequent subcultures were passed using standard trypsinization methods (Freshney 2000) following cellular proliferation to $\geq 95 \%$ confluence. Growth medium was replaced once per week without trypsinization if additional time was required for cells to reach confluence. Approx. $2 \mathrm{wk}$ following primary culture, antibiotics/antimycotics were removed from growth medium (MEM-20) to limit any potential negative effects associated with their continued use (Freshney 2000). At passage 40, FBS concentration was reduced to $10 \%$ (MEM-10) for all subsequent routine culture. Subcultures were diluted at ratios of 1:2 or 1:3 approximately $14 \mathrm{~d}$ for early $(<40)$ passages and was changed to $1: 3$ or 1:4 passed every 5 to $7 \mathrm{~d}$ for later passages.

Species authentication. Confirmation of species origin and detection of possible mixed species contamination or hybridization of BEF-1 cell line was performed by DNA sequence analysis of the cytochrome C oxidase subunit I (COI) gene of the mitochondrial DNA (Cooper et al. 2007). DNA was extracted from the BEF-1 cell line at passage 88 using the DNeasy ${ }^{\mathrm{TM}}$ tissue kit 250 (QIAGEN Inc.) following manufacturer's instructions. A 655 base pair (bp) region of the COI gene was amplified using primers and PCR conditions described by Ward et al. (2005). PCR products were visualized on a $1.6 \%$ agarose gel. Bidirectional sequencing was performed by Amplicon Express. Resulting sequences were analyzed and stored at the Barcode of Life Database (BOLD) (Ratnasingham \& Herbert 2007) and on GenBank (Benson et al. 2003).

Cryopreservation and recovery. Protocols for cell cryopreservation and recovery were performed based on those described by Freshney (2000). Briefly, cells in log phase growth were harvested by trypsinization, pelleted by centrifugation and re-suspended in Recovery $^{\mathrm{TM}}$ cell culture freezing medium (Gibco) to a concentration of $10^{6}$ to $10^{7}$ cells $\mathrm{ml}^{-1}$. Aliquots $(1.0 \mathrm{ml})$ were placed in cryovials (FisherScientific ${ }^{\circledR}$ ) and frozen at $-80^{\circ} \mathrm{C}$ at a rate of $1^{\circ} \mathrm{C} \mathrm{h}^{-1}$. After $24 \mathrm{~h}$, vials were transferred to liquid nitrogen. Cells were recovered by thawing frozen vials in a $37^{\circ} \mathrm{C}$ water bath. Viability was determined from a $50 \mu \mathrm{l}$ sample by hemocytometer counting after trypan blue staining. Remaining contents were transferred to a $75 \mathrm{~cm}^{2}$ flask where freezing medium was diluted drop wise with MEM-10 to a ratio of 1:20. Cells were incubated at $15^{\circ} \mathrm{C}$ and medium was replaced with fresh MEM-10 after $24 \mathrm{~h}$.

Optimization of conditions for cell growth. Cultures of BEF-1 at passages 75 to 80 were seeded into duplicate 12 -well tissue culture plates $\left(4.5 \mathrm{~cm}^{2}\right.$ well ${ }^{-1}$, FisherScientific $\left.{ }^{\circledR}\right)$ to a density of $1.7 \times 10^{4}$ cells $\mathrm{cm}^{-2}$. Total medium volume was brought to $1.2 \mathrm{ml}$ well ${ }^{-1}$. Baseline culture conditions consisted of MEM-10 (without antimicrobial chemicals) with an incubation temperature of $23^{\circ} \mathrm{C}$ unless otherwise specified. To assess effects of temperature, cultures were incubated at 4 , 15,23 , or $30^{\circ} \mathrm{C}$. To assess effects of FBS concentration, MEM was supplemented with 0, 2, 10, or $20 \%$ FBS. To assess sensitivity to PSN or Fungizone ${ }^{\mathrm{TM}}\left(2.5 \mu \mathrm{g} \mathrm{ml}^{-1}\right.$ amphotericin $B_{;}$E. R. Squibb and Sons), cultures were 
incubated with PSN antibiotic mix, Fungizone ${ }^{\mathrm{TM}}$, PSN antibiotic mix and Fungizone ${ }^{\mathrm{TM}}$, or without either antimicrobial. All cultures were incubated for $15 \mathrm{~d}$ with medium replaced at $9 \mathrm{~d}$. At $15 \mathrm{~d}$, average cell densities were calculated from replicate wells $(n=4)$ using a hemocytometer. Effects of temperature, FBS concentration, and the use of antibiotic/antimycotic chemicals on cell growth were compared by 1-way ANOVA using Graphpad Prism 2.01 on $\log _{10}$-transformed data. Pair wise comparisons were made using Tukey's test. Differences were considered significant at $\mathrm{p}<0.05$.

Karyotypic analysis. Chromosome preparations were made according to Earley (1975), with the exception that colcemid at a concentration of $0.2 \mu \mathrm{g} \mathrm{ml}^{-1}$ was used to arrest cells in metaphase by incubation for 4 to $6 \mathrm{~h}$. Cells were then incubated in a hypotonic solution with 1 part Hanks balanced salt solution (HBSS) to 4 parts distilled water, and chromosome spreads were prepared and stained as described by Earley (1975). Chromosome spreads of 100 cells were counted.

Viral susceptibility. The BEF-1 cell line was tested for susceptibility to infection by multiple strains of IHNV, IPNV, and VHSV (Table 1). Trials involving IHNV and IPNV were conducted at the University of Idaho, Moscow, USA using BEF-1 cultures at passage 80. Due to the regulatory status concerning VHSV in the United States and lack of its current detection in Idaho, all trials with VHSV genotypes were conducted at the Western Fisheries Research Center (WFRC), Seattle, USA using cultures at passage 95 . In both laboratories, analyses for viral infection and replication were performed based on those described by Lannan et al. (1984). Briefly, viral replication was assessed by infecting replicate BEF-1 cultures in $25 \mathrm{~cm}^{2}$ flasks at a multiplicity of infection (MOI) of 0.01 to 0.1 with each viral isolate and incubating the cultures at $15^{\circ} \mathrm{C}$ for $7 \mathrm{~d}$. Viral replication was determined by comparing viral titers at initial infection with titers obtained following $7 \mathrm{~d}$ incubation in BEF-1 cells. The $50 \%$ tissue culture infective dose $\left(\mathrm{TCID}_{50}\right)$ was determined as described by Reed and Muench (1938) using Chinook salmon embryo (CHSE-214; for IPNV) or epithelioma papulo- sum cyprini (EPC; for IHNV and VHSV) cell cultures. Viral susceptibility was assessed by inoculating 96well plates of BEF-1 cell cultures with $100 \mu \mathrm{L} \mathrm{well}^{-1}$ of viral stock solution for each viral isolate in progressive 10 fold serial dilutions. Similar trials were performed with CHSE-214 (for IPNV), and EPC (for IHNV and VHSV) for comparison. Following $12 \mathrm{~d}$ incubation at $15^{\circ} \mathrm{C}$, $\mathrm{TCID}_{50}$ values were calculated following formalin fixation and crystal violet staining.

Microscopy. Cell morphology and cytopathic effect were visualized using phase contrast microscopy. BEF1 cultures were inoculated with IPNV, IHNV, and VHSV isolates at a multiplicity of infection of 0.1 and incubated at $15^{\circ} \mathrm{C}$ for $4 \mathrm{~d}$. Cultures inoculated with IPNV and IHNV isolates were compared with uninfected controls at the University of Idaho using a Zeiss Axiovert 200M microscope at 20× magnification and images were recorded using an AxioCam HRm camera (Carl Zeiss). Cultures inoculated with VHSV isolates were compared with uninfected controls at the WFRC using a Zeiss microscope at $10 \times$ magnification and images were recorded using a Nikon D-70 camera.

\section{RESULTS}

\section{Establishment of burbot embryo cell line}

Primary culture of burbot embryo cells resulted in heterogeneous cell types adhering to the culture vessel. Cells in this primary culture divided slowly, requiring multiple exchanges of culture medium and a period of nearly $30 \mathrm{~d}$ before reaching $95 \%$ confluence. In subsequent subcultures, a slow trend of increased proliferation rate and decreased heterogeneity was observed. At passage 60, nearly 3 yr following primary culture, cell cultures appeared to be of a homogenous fibroblastic-like cell type. Cells replicated relatively quickly and would reach confluence after 3 to $4 \mathrm{~d}$ at $23^{\circ} \mathrm{C}$ following a $1: 3$ dilution. Contact inhibition between cells at this and subsequent passages was not observed. Cultures at passage 84 and 95 can be seen in

Table 1. Summary of viral isolates tested for BEF-1 susceptibility, isolated from Oncorhynchus spp. and Esox masquinongy. IPNV: infectious pancreatic necrosis virus; IHNV: infectious hematopoietic necrosis virus; VHSV: viral hemorrhagic septicemia virus

\begin{tabular}{|llcllll|}
\hline Isolate & Virus & $\begin{array}{c}\text { Serotype (S) } \\
\text { Genotype (G) }\end{array}$ & Host species & Location & Year & Source \\
\hline 94-434-1 & IPNV & A9 (S) & Cutthroat trout O. clarki & Clark Fork Hatchery, ID, USA & 1994 & Hill \& Way (1995) \\
Buhl & IPNV & A1(S) & Rainbow trout O. mykiss & Buhl, ID, USA & 1993 & LaPatra et al. (1993) \\
RB1 & IHNV & U (G) & Steelhead trout O. mykiss & Round Butte Hatchery, OR, USA & 2000 & Anderson et al. (2000) \\
$220-90$ & IHNV & M (G) & Rainbow trout O. mykiss & Buhl, ID, USA & 1990 & LaPatra et al. (1994) \\
Makah & VHSV & IVa (G) & Coho salmon O. kisutch & Makah Hatchery, WA, USA & 1988 & Batts et al. (1993) \\
MI03GL & VHSV & IVb (G) & Muskellunge E. masquinongy & Lake St. Clair, MI, USA & 2003 & Elsayed et al. (2006) \\
DKF1 & VHSV & I (G) & Rainbow trout O. mykiss & Egtved, Denmark & 1962 & Jensen (1965) \\
\hline
\end{tabular}



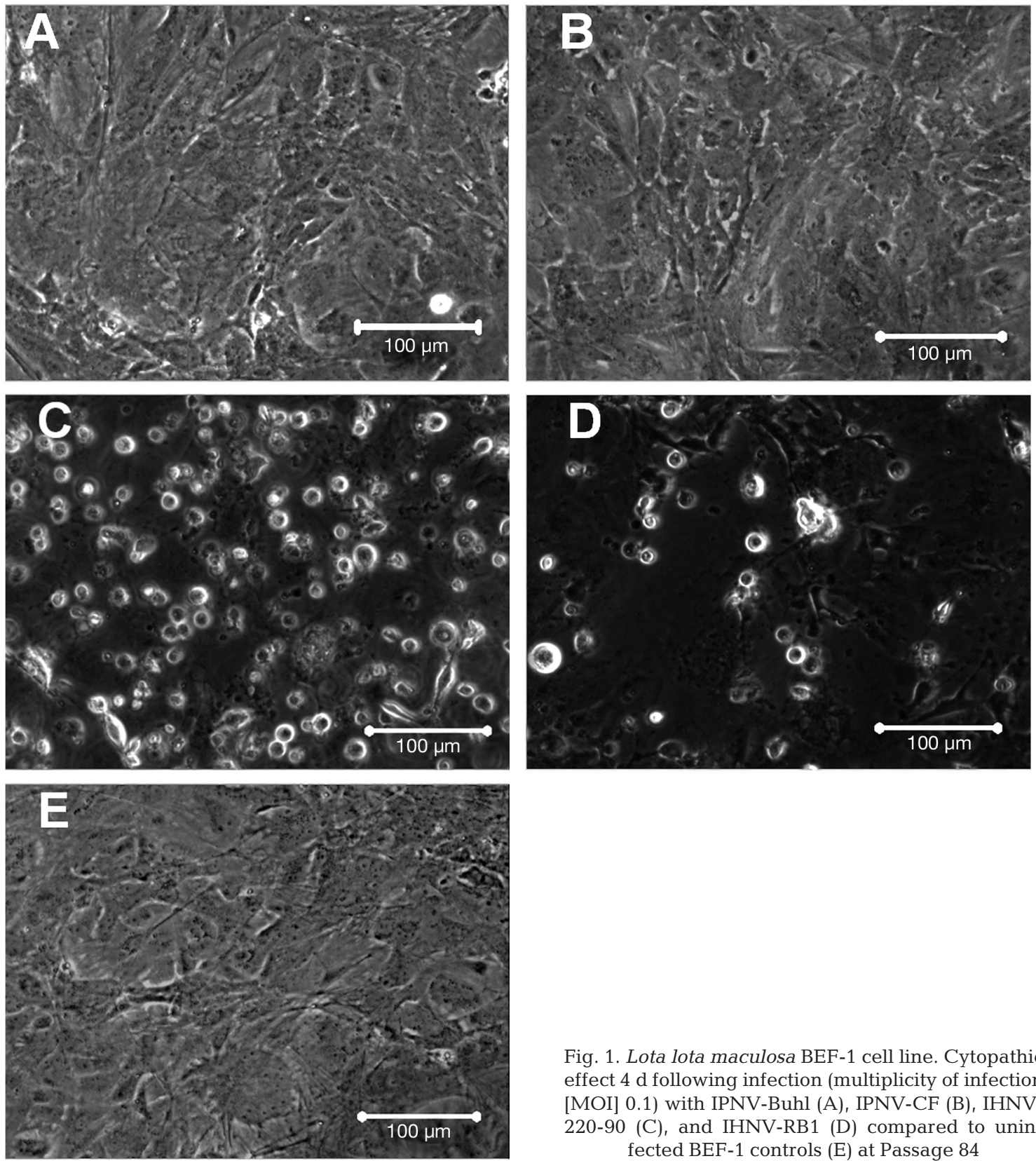

Fig. 1. Lota lota maculosa BEF-1 cell line. Cytopathic effect $4 \mathrm{~d}$ following infection (multiplicity of infection [MOI] 0.1) with IPNV-Buhl (A), IPNV-CF (B), IHNV220-90 (C), and IHNV-RB1 (D) compared to uninfected BEF-1 controls (E) at Passage 84

Fig. 1E and Fig. 2D respectively. Cryopreservation was achieved for multiple BEF-1 cultures between passages 40 and 100 . Cell viability of $>90 \%$ was typically observed from thawed stocks after 1 to 24 mo in liquid nitrogen storage. Cells could be grown to confluence following cryopreservation in $<7 \mathrm{~d}$.

\section{Species authentication and karyotypic analysis}

Sequence analysis of the COI gene from cultured BEF-1 cells at passage 80 demonstrated $100 \%$ proba- bility of species placement to the Gadidae family and Lotidae subfamily, with $99.4 \%$ placement to genus Lota using the BOLD specimen identification system (www.barcodinglife.org). A taxonomic tree generated by BOLD for this cell line can be seen in Fig. 3. Sequence data for the COI gene generated for the BEF-1 cell line can be viewed in the BOLD database (BEF001-09) and GenBank (GU126680). Karyotypic analysis revealed a modal chromosome number of 48 for the BEF-1 cell line. However, chromosome numbers ranged from 28 to 74 with a slight bimodal distribution (Fig. 4). 

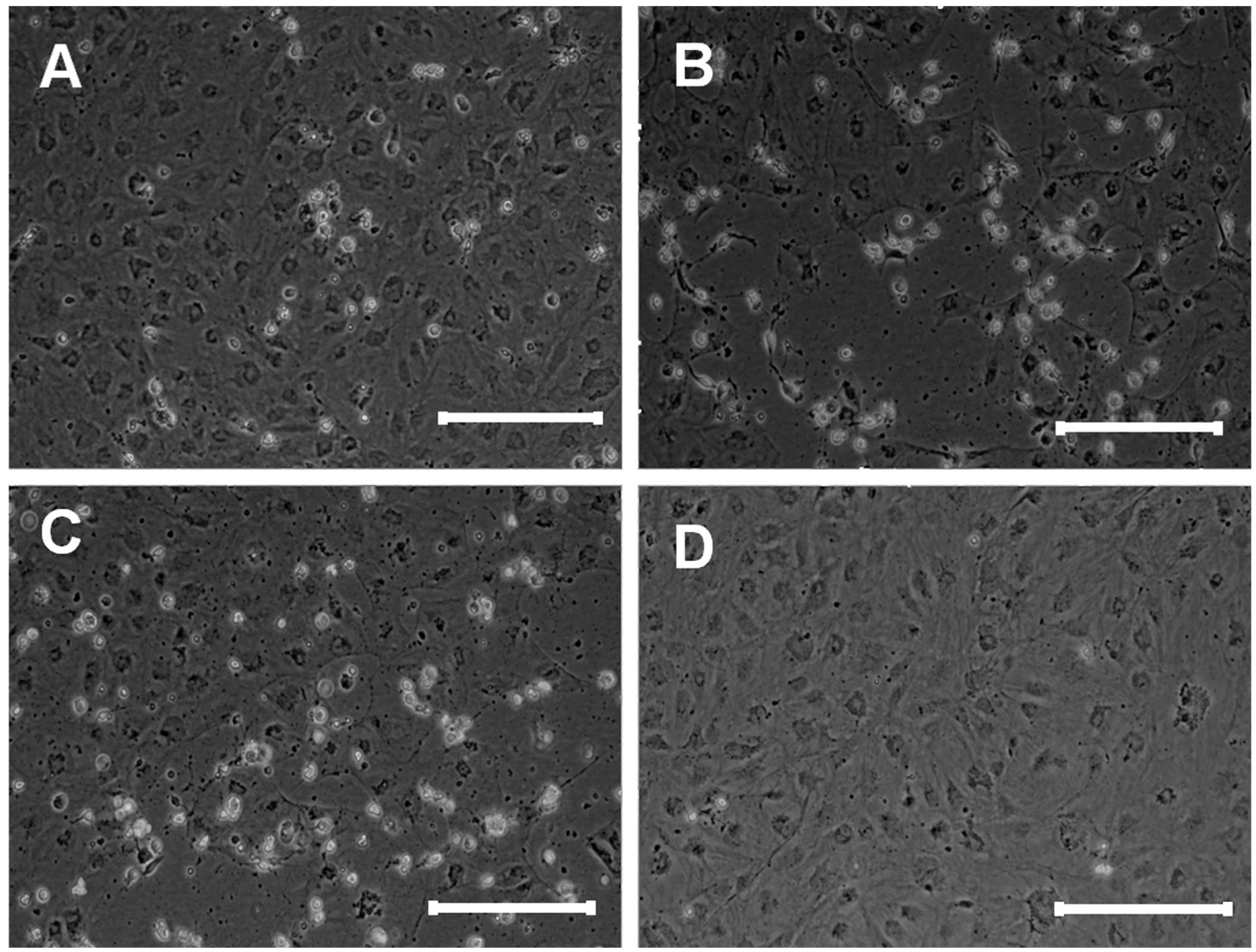

Fig. 2. Lota lota maculosa BEF-1 cell line. Cytopathic effect 10 d following infection (MOI 0.01) with VHSV-IVa (A), VHSV-IVb (B), and VHSV-I (C) compared to uninfected BEF-1 controls (D) at Passage 95. Scale bar $=1 \mathrm{~mm}$

\section{Optimization of conditions for in vitro growth}

Temperature, FBS concentration, and the use of Fungizone $^{\mathrm{TM}}$ antimycotic solution significantly affected BEF-1 cell growth (Fig. 5). Maximum growth was observed in BEF-1 cultures at temperatures of 15 and $23^{\circ} \mathrm{C}$, where 0.64 and $0.68 \log$ increases in cell concentration were observed following $15 \mathrm{~d}$ incubation respectively. At $4^{\circ} \mathrm{C}$, cell density at $15 \mathrm{~d}$ was comparable to the initial stocking concentration, as an initial drop in cell number was observed followed by minimal protracted growth during the rest of the $15 \mathrm{~d}$ period. Cell death was observed in cultures incubated at $30^{\circ} \mathrm{C}$, where a 0.89 log reduction in cell concentration was observed relative to initially stocked density following $15 \mathrm{~d}$ incubation (Fig. 1). Nevertheless, scattered foci of proliferating cells were observed during this period indicating an ability for sub-populations of these cells to replicate (at least to a limited degree) at this temperature.

BEF-1 cells cultured in the absence of FBS demonstrated minimal growth (Fig. 5). Cell concentration decreased in the first day following stocking, but recovered slowly to comparable initial stocking densities by the end of the $15 \mathrm{~d}$ trial. A $0.12 \log$ increase in growth was observed with the addition of $2 \%$ FBS, and a 0.45 $\log$ increase was observed with the addition of $10 \%$ FBS following $15 \mathrm{~d}$ incubation. Increasing supplementation of FBS to $20 \%$ did not appear to influence cell replication compared to cells cultured with $10 \%$ FBS.

The addition of PSN did not affect cell growth or morphology (Fig. 5). In contrast, the use of Fungizone $^{\mathrm{TM}}$ significantly reduced cell growth and cells became rounded and granulated in the presence of this chemical. There was a $0.62 \log$ reduction in cell density relative to untreated controls. Synergistic effects between PSN and Fungizone ${ }^{\mathrm{TM}}$ were not observed, as cells grown in the presence of Fungizone ${ }^{\mathrm{TM}}$ with or without PSN were comparable.

\section{Characterization of viral susceptibility}

All isolates of IHNV and VHSV tested were able to replicate in the BEF-1 cells. High viral titers and extensive cytopathic effect were observed (Table 2; Fig. 1B, $C_{i}$ Fig. 2A, B, C), demonstrating susceptibility of the 


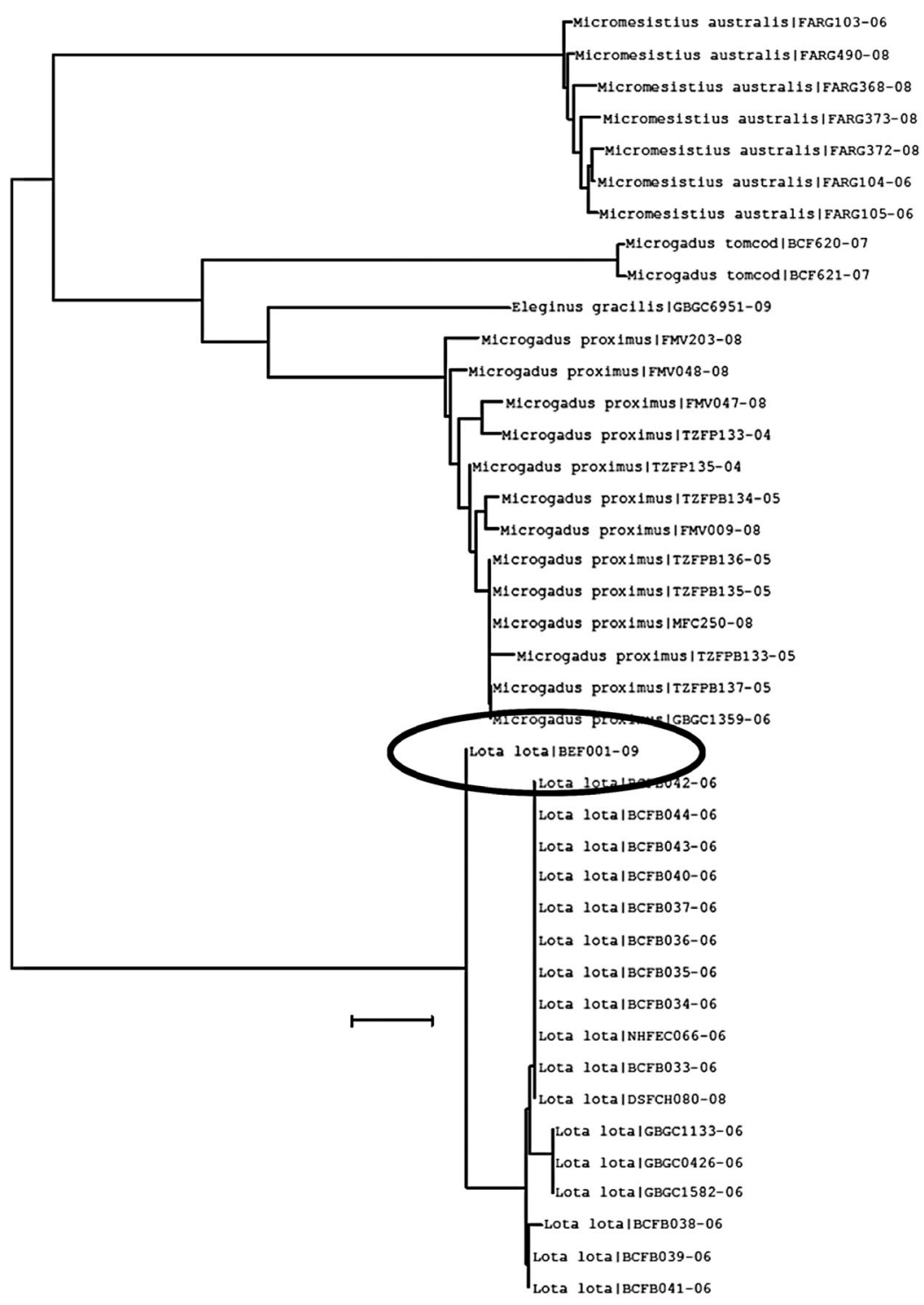

Fig. 3. Lota lota maculosa BEF-1 cell line. Taxonomic neighbor joining (NJ) tree generated using the Identification Engine at the Barcode of Life database (bold; www.barcodinglife.org). BEF-1 sequence is compared to closely related field specimens. Scale bar $=1 \%$ sequence divergence

burbot derived BEF-1 cell line to the IHNV and VHSV genotypes tested. However, the susceptibility of BEF-1 was lower in all cases when compared with EPC cultures (Table 3). The highest susceptibility of BEF-1 cultures was observed with the $\mathrm{M}$ genotype isolate of IHNV (220-90), where a one log $\mathrm{TCID}_{50} \mathrm{ml}^{-1}$ reduction compared with the EPC cultures was observed. Susceptibility was slightly lower to the U genotype of IHNV (RB1) as well as the IVb and I genotype isolates of VHSV (MI03GL and DKF1 respectively), where approx. a $2 \log \mathrm{TCID}_{50} \mathrm{ml}^{-1}$ reduction was observed compared with the EPC cultures. Minimal sensitivity to VHSV genotype IVa isolate was observed. In this instance, a $7 \log \mathrm{TCID}_{50} \mathrm{ml}^{-1}$ lower titer was produced in BEF-1 cell cultures relative to EPC cell cultures.

None of the isolates of IPNV used in this study replicated in BEF-1 cells (Table 2) or induced cytopathic effect (Fig. 1A, B) during experimental trials. Thus, the BEF-1 cell line appeared to be refractory to IPNV, even at high viral titers (Table 3). Blind passage to fresh cell monolayers was not performed.

\section{DISCUSSION}

In this study, we have described the development and partial characterization of a burbot cell line, which may be useful for the detection and replication of intracellular pathogens of burbot and other related fish species. Previous work has identified the need for such cell lines to identify viral pathogens that may target specific species (Hedrick et al. 1991). The distribution of this representative burbot cell line to diagnostic laboratories should enhance the ability to effectively monitor and screen burbot for new or emerging pathogens. The BEF-1 cell line developed here provides a potentially important tool for fish health specialists.

A preferred temperature range of 15 to $23^{\circ} \mathrm{C}$ was observed for BEF-1 culture and is similar to that in other coldwater fish cell lines (Lannan et al. 1984). The upper thermo-tolerance was observed to be approximately $30^{\circ} \mathrm{C}$, although a small proportion of the BEF-1 cells incubated at $30^{\circ} \mathrm{C}$ were observed to multiply in isolated foci, suggesting some BEF-1 cells have an ability (or can adapt) to replicate at this elevated temperature; an ability that has not been observed in other coldwater salmonid cell lines (Lannan et al. 1984).

As with most vertebrate cell lines where serum is usually essential for in vitro culture (Freshney 2000, Cartwright \& Shah 2002), serum, in the form of FBS, is required for culture of BEF-1 cells. Cultures maintained in the absence of FBS failed to substantially replicate (Fig.5). Satiation of FBS was observed at a concentration of approximately $10 \%$, as increased supplementation beyond $10 \%$ did not produce additional proliferative benefit (Fig. 5). Therefore, it is recommended that FBS be supplemented to $10 \%$ to optimize BEF-1 cell replication. 


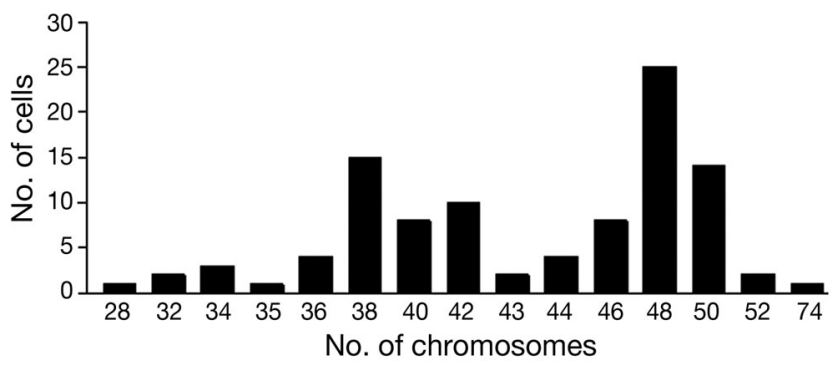

Fig. 4. Lota lota maculosa BEF-1 cell line. Chromosome number distribution at Passage 95. In total, 100 metaphases were counted

The BEF-1 cell line showed sensitivity to the polyene macrolide amphotericin B (Fungizone). Cell proliferation decreased by nearly $75 \%$, and granulation and cell rounding possibly due to toxicity was observed. Polyene macrolides have previously been shown to alter membrane function and reduce cell proliferation in other species and cell types, although such effects have been variable (Fisher et al. 1978, Butterworth 1982). The aminoglycosides neomycin and streptomycin, as well as the beta-lactam penicillin, did not appear to produce any deleterious effects in BEF-1 cell culture, but their efficacy as antimycotics is limited and future consideration should be given to alternative fungicidal chemicals if required.
Table 2. Lota lota maculosa cell line BEF-1. IPNV, IHNV and VHSV replication. Viral titers determined by inoculating BEF-1 cell culture media onto CHSE-214 (IPNV) or EPC (IHNV and VHSV) cells at 0 and $7 \mathrm{~d}$ post inoculation

\begin{tabular}{|lcc|}
\hline Virus & $\begin{array}{c}\text { Viral titer } \\
\text { Day 0 }\end{array}$ & $\begin{array}{c}\left.\text { (log } \mathrm{TCID}_{50} \mathrm{ml}^{-1}\right) \\
\text { Day } 7\end{array}$ \\
\hline IPNV (A9) & 4.7 & 4.4 \\
IPNV (A1) & 4.7 & 4.3 \\
IHNV (U) & 4.6 & 8.2 \\
IHNV (M) & 4.2 & 8.3 \\
VHSV (IVa) & 1.7 & 3.5 \\
VHSV (IVb) & 2.4 & 6.0 \\
VHSV (I) & 2.5 & 6.6 \\
\hline
\end{tabular}

The use of PCR COI barcoding identified the BEF-1 cell line to its expected species of origin following 80 in vitro passages. Such authentication is considered an important aspect for the laboratory use of cell lines (Cooper et al. 2007) as significant portions of research, specifically involving human and primate research (Stacey 2000), has been misleading due to improper identification or cross-contamination of the cell lines being used. Karyotypic analysis can also be used to characterize a cell line for species of origin, but additionally provides indication for chromosomal rearrangement and aberrations (Earley 1975, Freshney

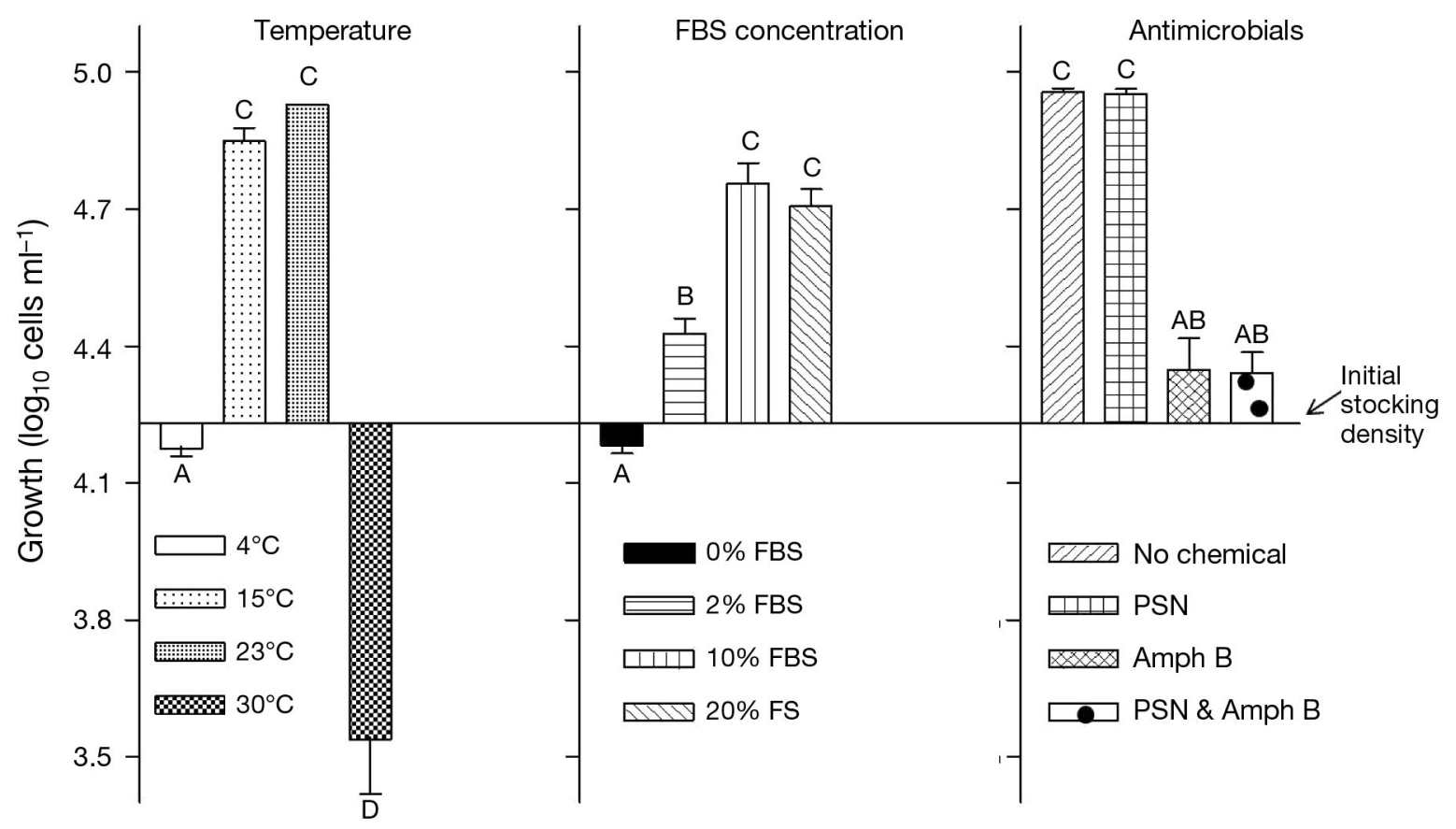

Fig. 5. Lota lota maculosa BEF-1 cell line. Effects of temperature, fetal bovine serum (FBS) concentration, and antibiotics on cell growth (mean $\pm \mathrm{SE} ; \mathrm{n}=4$ ) following $15 \mathrm{~d}$ incubation. Letters above columns indicate significantly different values within and between treatments $(\mathrm{p}<0.05)$. Growth media consisted of minimal essential medium (MEM) supplemented to $10 \%$ FBS without antibiotics incubated at $23^{\circ} \mathrm{C}$ unless otherwise specified. PSN: penicillin-streptomycin-neomycin $\left(0.05,0.05,0.1 \mathrm{mg}^{-1}\right)^{-1}$ Amph B: Fungizone ${ }^{\mathrm{TM}}$ amphotericin B $\left(2.5 \mu \mathrm{g} \mathrm{ml}^{-1}\right)$ 
Table 3. Lota lota maculosa BEF-1 cell line. Sensitivity in detection of IPNV, IHNV, and VHSV by TCID $_{50}$ assay following $12 \mathrm{~d}$ incubation. ND: not done; 0: no cytopathic effect observed

\begin{tabular}{|lccc|}
\hline \multirow{2}{*}{ Virus } & \multicolumn{3}{c|}{ Virus detected (log TCID } \\
& BEF-1 & ml-1) \\
& & CHSE-214 & EPC \\
\hline IPNV (A9) & 0 & 7.4 & ND \\
IPNV (A1) & 0 & 8.3 & ND \\
IHNV (U) & 6.5 & ND & 8.4 \\
IHNV (M) & 7.0 & ND & 8.0 \\
VHSV (IVa) & 3.5 & ND & 10.5 \\
VHSV (IVb) & 6.7 & ND & 8.9 \\
VHSV (I) & 6.0 & ND & 8.5 \\
\end{tabular}

2000). The modal diploid chromosome number for the BEF-1 cell line was 48, which corresponds to the chromosome number described for burbot (Rab 1986). Previous research has shown a considerable karyotypic heterogeneity in cods, which was also demonstrated in the BEF-1 cell line by divergence from the standard karyotypic number (Fig. 4). However, techniques employed to produce chromosome spreads may not be $100 \%$ efficient, may result in falsely variable or low counts (Earley 1975), and may explain some of the divergence in chromosome numbers observed here and in previous studies. Thus, although cells transformed for continuous in vitro culture typically show higher divergence and aberrations in chromosome number and morphology, we are reluctant to make claims concerning chromosome aberration or cell line transformation of BEF-1 due to the presumed natural heterogeneity and possibility for falsely representative counts. Nevertheless, given the increased replication, apparent lack of contact inhibition, and lengthy duration of laboratory culture and passage number, it is highly likely that the BEF-1 cell line has undergone some form of transformation that has been expressed to some degree in chromosomal aberration.

The BEF-1 cell line was shown to be susceptible to multiple isolates of IHNV and VHSV; 2 prominent and highly pathogenic Novirhabdoviruses of fish. However, the degree of susceptibility of BEF-1 cells was lower compared with other previously established cell lines (Table 3). It is interesting to note that in vivo challenge experiments have also indicated susceptibility to IHNV at the whole organism level (Polinski et al. in press). In vivo trials have not been attempted for VHSV; however, given that this virus has been isolated from wild burbot stocks (USDA-APHIS 2007) and was observed to replicate in the BEF-1 cell line here, it may be advisable to consider burbot as susceptible to VHSV for the purposes of management.

The BEF-1 cell line appeared refractory to IPNV, as CPE was not observed in this trial (Fig. 1) and viral replication was not evident out to $7 \mathrm{~d}$ post inoculation (Table 2). Subsequent trials in which BEF-1 infected cultures were monitored for up to $21 \mathrm{~d}$ confirmed these observations as CPE was not apparent (data not shown). We conclude that the continuous BEF-1 cell line developed here is not suitable for detection of IPNV.

In summary, this study outlines the development of a continuous fibroblastic-like cell line from burbot with characterization in regard to in vitro replication and susceptibility to 3 prominent viruses of fish. This cell line is the first continuous cell line to be described in the cod family, and provides a laboratory tool for further research and pathogen monitoring of burbot and possibly other Gadidae species.

Acknowledgements. Funding for this work was provided by the Kootenai Tribe of Idaho through contracts with Bonneville Power Administration (Project \#198806400/Contract \#30729 and 37267) and the United States Geological Survey. We thank N. Lindstrom for laboratory assistance with cell culture procedures and J. Winton at the Western Fish Disease Laboratory, along with A. Norton at the University of Idaho Department of Microbiology Molecular Biology and Biochemistry for critical help in the capturing cell culture images. Assistance with karyotypic analysis was given by G. Thorgaard and P. Wheeler at Washington State University.

\section{LITERATURE CITED}

Anderson ED, Engelking HM, Emmenegger EJ, Kurath G (2000) Molecular epidemiology reveals emergence of a virulent infectious hematopoietic necrosis (IHN) virus strain in wild salmon and its transmission to hatchery fish. J Aquat Anim Health 12:85-99

Babich H, Borenfreund E (1991) Cytotoxicity and genotoxicity assays with cultured fish cells: a review. Toxicol In Vitro 5:91-100

Batts W, Arakawa CK, Bernard J, Winton JR (1993) Isolates of viral hemorrhagic septicemia virus from North America and Europe can be detected and distinguished by DNA probes. Dis Aquat Org 17:67-71

> Benson DA, Karsch-Mizrachi I, Lipman DJ, Ostell J, Wheeler DL (2003) GenBank. Nucleic Acids Res 31:23-27

Bols NC, Lee LEJ (1991) Technology and uses of cell cultures from the tissues and organs of bony fish. Cytotechnology 6:163-187

Butterworth J (1982) Effects of econazole, fungizone and pimafucin on cell growth, lysosomal enzyme activity and sulphate metabolism of cultured human skin fibroblasts and amniotic fluid cells. J Inherit Metab Dis 5:187-191

Cartwright T, Shah GP (2002) Growth media. In: Davis JM (ed) Basic cell culture, 2nd edn. Oxford University Press, New York, p 69-106

Cooper JK, Sykes G, King S, Cottrill K, Ivanova NV, Hanner $\mathrm{R}$, Ikonomi P (2007) Species identification in cell culture: a two-pronged molecular approach. In Vitro Cell Dev Biol Anim 43:344-351

Earley EM (1975) Chromosome preparations from monolayer cell cultures. TCA Man 1:31-35

- Elsayed E, Faisal M, Thomas M, Whelan G, Batts W, Winton JR (2006) Isolation of viral hemorrhagic septicemia virus from muskellunge, Esox masquinongy (Mitchill), in Lake 
St. Clair, Michigan, USA reveals a new sublineage of the North American genotype. J Fish Dis 29:611-619

Fisher SJ (2000) Early life history observations of burbot utilizing two Missouri River backwaters. In: Paragamian VL, Willis DW (eds) Burbot: biology, ecology, and management. Fisheries Management Section of the American Fisheries Society, Spokane, WA, p 96-102

Fisher PB, Bryson V, Schaffner C (1978) Polyene macrolide antibiotic cytotoxicity and membrane permeability alterations: comparative effects on four classes of polyene macrolides on mammalian cells. J Cell Physiol 97:345-352

Freshney RI (2000) Culture of animal cells, 4th edn. WileyLiss, New York

Fryer JL, Lannan CN (1994) Three decades of fish cell culture: a current listing derived from fishes. J Tissue Cult Methods 16:87-94

Hedrick RP, McDowell TS, Rosemark R, Aronstein D, Lannan CN (1991) Two cell lines from white sturgeon. Trans Am Fish Soc 120:528-534

Hill BJ, Way K (1995) Serological classification of infectious pancreatic necrosis (IPN) virus and other aquatic birnaviruses. Annu Rev Fish Dis 5:55-77

Jensen MH (1965) Research on the virus of Egtved disease. Ann NY Acad Sci 126:422-426

- Jensen NR, Ireland SC, Siple JT, Williams SR, Cain KD (2008) Evaluation of egg incubation methods and larval feeding regimes for North American burbot. N Am J Aquaculture 70:162-170

Jensen NR, Williams SR, Ireland SC, Siple JT, Neufeld MD, Cain KD (2008b) Preliminary captive burbot spawning observations. In: Paragamian VL, Bennett DH (eds) Burbot: ecology, management, and culture, symposium 59. American Fisheries Society, Bethesda, MD, p 155-166

Jensen NR, Zuccarelli MD, Patton SJ, Williams SR, Ireland SC, Cain KD (2008c) Cryopreservation and methanol effects on burbot sperm motility and egg fertilization. N Am J Aquaculture 70:38-42

Lannan CN, Winton JR, Fryer JL (1984) Fish cell lines: establishment and characterization of nine cell lines from salmonids. In Vitro 20:671-679

LaPatra SE, Lauda KA, Woolley MJ, Armstrong R (1993) Detection of a naturally occurring coinfection of IHNV and IPNV in rainbow trout. American Fisheries Society. Fish Health Section Newsl 21:9-10

LaPatra SE, Lauda KA, Jones GR (1994) Antigenic variants of infectious hematopoietic necrosis virus and implications for vaccine development. Dis Aquat Org 20:119-126

McPhail JD, Paragamian VL (2000) Burbot biology and life history. In: Paragamian VL, Willis DW (eds) Burbot: biology, ecology and management. Fisheries Management Section of the American Fisheries Society, Spokane, WA, p 11-24

Nicholson BL (1989) Fish cell culture: an update. In: Maramorosch K, Sato GH (eds) Advances in cell culture, 7th

Editorial responsibility: Mark Crane,

Geelong, Victoria, Australia edn. Academic Press, New York, p 1-18

OIE (Office International des Epizooties) (2003) Diagnostic manual for aquatic animal diseases. OIE, Paris, 212-217

Paragamian VL (2000) The effects of variable flows on burbot spawning migrations in the Kootenai River, Idaho, USA, and Kootenay Lake, British Columbia, Canada, after construction of the Libby Dam. In: Paragamian VL, Willis DW (eds) Burbot: biology, ecology, and management. Fisheries Management Section of the American Fisheries Society, Spokane, WA, p 111-126

Paragamian VL, Willis DW (eds) (2000) Burbot: biology, ecology and management. Fisheries Management Section of the American Fisheries Society, Spokane, WA

Paragamian VL, Whitman V, Hammond J, Andrusak H (2000) Collapse of burbot fisheries in the Kootenai River, Idaho, USA, and Kootenay Lake, British Columbia Canada. In: Paragamian VL, Willis DW (eds) Burbot: biology, ecology, and management. Fisheries Management Section of the American Fisheries Society, Spokane, WA, p 155-164

Polinski MP, Fehringer TR, Johnson KA, Snekvik KR and others (in press) Characterization of susceptibility and carrier status of burbot, Lota lota (LeSueur), to IHNV, IPNV, Flavobacterium psychrophium, Aeromonas salmonicida, and Renibacterium salmoninarum. J Fish Dis, doi: 10.1111/j.1365-2761.2010.01152.x

Pulliainen E, Korhnonen K, Kankaanranta L, Maeki K (1992) Non-spawning burbot on the northern coast of the Bothnian Bay. Ambio 21:170-175

Rab P (1986) Karyotype of the European burbot, Lota lota (Gadidae). J Ichthyol 26:127-131

Ratnasingham S, Herbert PDN (2007) BOLD: the barcode of life data system (www.barcodinglife.org). Mol Ecol Notes $7: 355-364$

Reed L, Muench H (1938) A simple method of estimating fifty percent endpoints. Am J Hyg 27:493-497

Shiri Harzevili A, De Charleroy D, Auwerx J, Vught I, Van Slycken J, Dhert P, Sorgeloos P (2003) Larval rearing of burbot (Lota lota L.) using Brachionus calyciflorus rotifer as starter food. J Appl Ichthyol 19:84-87

Stacey GN (2000) Cell contamination leads to inaccurate data: we must take action now. Nature 403:356

USDA-APHIS (United States Department of Agriculture-Animal and Plant Health Inspection Service (2007) USDA viral hemorrhagic septicemia-susceptible species list. Annapolis, MD

Vught I, Harzevilli AS, Auwerx J, De Charleroy D (2008) Aspects of reproduction and larviculture of burbot under hatchery conditions. In: Paragamian VL, Bennett DH (eds) Burbot: ecology, management, and culture. Symposium 59, American Fisheries Society, Bethesda, MD, p 167-178

Ward RD, Zemlak TS, Innes BH, Last P R, Hebert PDN (2005) DNA barcoding Australia's fish species. Philos Trans R Soc B Biol Sci 360:1847-1857

Submitted: October 26, 2009; Accepted: February 10, 2010 Proofs received from author(s): April 13, 2010 